Saint Louis University School of Law

Scholarship Commons

All Faculty Scholarship

2002

\title{
Official Privilege: State Security and the Right to a Fair Trial in the USA
}

Stephen C. Thaman

Follow this and additional works at: https://scholarship.law.slu.edu/faculty

Part of the Comparative and Foreign Law Commons, $\underline{\text { Criminal Law Commons, and the Criminal }}$ Procedure Commons 


\title{
OFFICIAL PRIVILEGE; STATE SECURITY AND THE RIGHT TO A FAIR TRIAL IN THE USA
}

\author{
Stephen C. Thaman
}

\section{Introduction}

The rights to compulsory process, confrontation of opposing witnesses and due process ${ }^{1}$ guaranty the accused the right to present all relevant and material exculpatory evidence at trial, either through cross-examination of prosecution witnesses $^{2}$ or presentation of its own witnesses or other evidence. ${ }^{3}$ But the requirements of American adversary procedure set many traps which hinder the realization of these rights, among which are:

(1) a restrictive practice of discovery of the evidence gathered by law enforcement;

(2) privileges of confidentiality and other state interests which hinder the revelation of important information;

(3) rules of evidence and testimonial privileges which hinder the introduction of evidence, and, finally;

Herwig Roggemann and Petar Sarcevic, National Security and International Criminal Justice, 25-36.

(C) 2002 Kluwer Law International. Printed in the Netherlands.

"Prof. Dr. Stephen C. Thaman teaches Criminal Law and Procedure and Comparative Law at the Saint Louis University, St. Louis.

${ }^{1}$ U.S.Const. V. \& XIV. Amendments.

${ }^{2}$ See Davis v. Alaska, 415 U.S. 308,318 (1974); Olden v. Kentucky, 488 U.S. 227

${ }^{3}$ Washington v. Texas, 388 U.S. 14, 19 (1967). (The compulsory process clause guarantees 'the right to offer the testimony of witnesses, and to compel their attendance and the right to present the defendant's version of the facts.').

H. Roggemann and P. Sarčevic (eds.), National Security and Intemational Criminal Justice, 25-36.

C 2002 Kluwer Law International. Printed in the Netherlands. 
(4) prohibitions on the use of evidence which may be imposed as a result of the violation by the defence of a duty to reveal evidence.

The main emphasis of this paper will be on the effect of the state claiming a privilege of national security in a criminal case, either to:

(1) prevent the defendant from gaining discovery of classified information which could be important in defending against the criminal charges; or

(2) prevent the defendant from introducing classified evidence in his/her own defence, access to which has usually been gained by virtue of the defendant's own activity with the intelligence services (CIA, FBI) or other police agencies.

Before discussing the Classified Information Procedures Act (CIPA) which regulates the handling of such claims, we will briefly summarize the effect of statutory and case law regarding discovery of evidence favorable to the defence and then discuss the doctrines relating to protecting and/or piercing official privileges of confidentiality in normal criminal cases. Parallels will seen in all these areas: The state often claims national security in situations where the state itself is either dealing with criminals or using criminal methods in conducting normal criminal investigations, or, as in cases under the CIPA, in conducting foreign or domestic policy.

\section{Discovery Law-Especially in Relation to Police Informants}

In the U.S. the prosecution has, in principle, no duty to look for and preserve evidence which could exculpate or otherwise be helpful to the defendant in conducting his/her defence. ${ }^{5}$ If, however, evidence that is clearly exculpatory or otherwise beneficial to the defence ends up in the hands of law enforcement, the prosecution is obliged to reveal such evidence or it will constitute a violation of the defendant's right to due process under the $5^{\text {th }}$ and $14^{\text {th }}$ Amendments of the U.S. Constitution. ${ }^{6}$ This due process right of the defendant has been limited in its importance by subsequent decisions of the U.S. Supreme Court which held that the withholding of exculpatory or other helpful evidence from the defence will not

${ }^{4}$ Although the prosecution could conceivably move to introduce national security information to gain a conviction, this problem scarcely arises when the prosecutor is part of the same executive branch of government which seeks to keep the information secret, i.e., in the unified federal system. The problem could conceivably arise when a state prosecutor seeks national security information to use in a state criminal trial.

${ }^{5}$ In re Michael L., 216 Cal.Rptr. 140 (Cal. 1985).

${ }^{6}$ Brady v. Maryland, 373 U.S. 83, 87 (1968). Without a defence discovery motion, however, a violation of due process only exists if their introduction of such evidence at trial would have raised a reasonable doubt as to the guilt of the defendant. United States $v$. Agurs, 427 U.S. 97, $112-113$ (1976). 
result in reversal of a conviction, unless 'there is a reasonable probability that... the result of the proceedings would have been different'? This decision leaves it up to the prosecution to make a tactical decision to withhold possibly exculpatory evidence in hopes that the reviewing courts will decide that the evidence would not have affected the jury's verdict in the case.

This limitation is especially important in cases in which the prosecutor has used undercover informants or witnesses out of the criminal milieu to prove its case and withholds evidence of promises, payments, prior convictions, or other conduct which could be used by the defendant to impeach the credibility of the informant-witness at trial. ${ }^{8}$ The withholding of potential impeachment evidence may also violate the defendant's right to cross-examine opposing witnesses. ${ }^{9}$

\section{Collision Between Rights of the Defence and Official Privilege (General)}

When a subpoena or discovery request triggers a collision between the rights of the defence and official state privileges of confidentiality, the requested information must be turned over to the defence if its withholding would violate the defendant's due process rights, ${ }^{10}$ or rights to compulsory process or confrontation of the witnesses for the prosecution. " Even if the state is responsible for the unavailability of witness who could potentially aid the defendant, the appellate

'United States v. Bagley, 473 U.S. 667 (1985). Strangely enough this is not an application of the "harmless error' rule. If the evidence would not have led to a different result, there was no due process violation in the first place. Thus in Strickler v. Greene, 527 U.S. 263 (1999), the U.S. Supreme Court upheld a death sentence after determining that, while the prosecution withheld evidence that would have impeached the testimony of a significant eyewitness to a kidnapping-murder, its introduction at trial would not have changed the outcome of the case.

${ }^{8}$ The Federal Rules of Evidence permit introduction of a wide range of evidence to impeach witnesses. See FRE 607 et seq, 780.

${ }^{9}$ Davis v. Alaska, 417 U.S. 308 (1974).

${ }^{10}$ Pennsylvania v. Ritchie, 480 U.S. 39 (1987) (Accused of sexual molestation of his daughter, the defendant moves for discovery of youth protection records relating to his daughter which are protected by a state confidentiality privilege. The refusal of the trial judge to review the documents in an in camera hearing constituted a violation of the due process rights of the defendant.).

${ }^{11}$ Davis v. Alaska, 415 U.S. 308 (1974) (The right of the defendant to confront a juvenile prosecution witness was violated because a privilege of confidentiality for information related to the juvenile criminal record of the witness prevented the disclosure of prior convictions and other evidence which could have impeached the credibility of the witness at trial.). 
courts require proof that the witness actually could have provided exculpatory testimony for the defence. ${ }^{12}$

The usual procedure to deal with motions for discovery of confidential information can best be illustrated in relation to two of the most common examples in U.S. criminal practice:

(1) the discovery of the personnel file of police officers or other agents in order to find impeachment material; and

(2) the revelation of the identity of undercover informants who are material witnesses of the criminal act charged to the defendant.

When the identity of an undercover informant or the content of his statements are relevant and helpful to the defence or necessary to a just decision of the guilt question, the privilege of confidentiality must yield. ${ }^{13}$

In California there is a privilege of confidentiality in relation to citizen's complaints against police officers alleging acts of violence or other unlawful conduct. $^{14}$ If the defendant claims self-defence in a prosecution for using violence against a police officer, evidence of the officer's earlier use of excessive force or his racial prejudice, which is often contained in the officer's personnel file following a citizen's complaint, is both relevant and subject to disclosure. ${ }^{15}$

In criminal trials in which the credibility of the police officer is a crucial issue, the prosecutor must, following a reasoned defence motion, search in the personnel file of the police witness for information relating to earlier instances of perjury or dishonesty. ${ }^{16}$ Earlier instances of intimidation by an undercover informant are also admissible where the defendant interposes the excuse of entrapment to defend against a crime he committed following encouragement of the informant. ${ }^{17}$

In California specific laws regulate the procedure for discovery of information in the personnel files of police officers ${ }^{18}$ and for the revelation of the identity of an undercover informant. ${ }^{19}$ In a written motion the defence must

${ }^{12}$ United States v. Valenzuela-Bernal, 458 U.S. 858,863 (1982) (Eyewitnesses were deported by the Immigration and Naturalization Service before the defence could interview them.).

${ }^{13}$ Roviaro v. United States, 353 U.S. 53, 62 (1957). The criteria for balancing in the Roviaro decision are incorporated in Cal. Evid. Code $\S 104 \mathrm{I}$, according to which the privilege of confidentiality must yield in cases involving undercover informants 'in the interests of justice'.

${ }^{14}$ Cal. Penal Code $\$ \S 832.7-832.8$.

${ }^{15}$ Pitchess v. Superior Court, 113 Cal. Rptr. 897 (Cal. 1974).

${ }^{16}$ United States v. Henthorn, 931 F.2d 29 (9 ${ }^{\text {th }}$ Cir. 1991). People v. Daniels, 52 Cal.3d 815, 854-855 (1991).

${ }^{17}$ United States v. McClure, 546 F.2d $670\left(5^{\text {th }}\right.$ Cir. 1977).

${ }^{18}$ Cal. Evid. Code $\$ \S 1043$ et seq.

${ }^{19}$ Cal. Evid. Code $\$ \S 1041,1042$. See also Fla. R. Crim. P. 3.220(g)(2); Ill. Rev. Stat. Ch. $110 \mathrm{~A} \$ 412(j)(\mathrm{ii})$. 
specifically allege what evidence it is searching for in the personnel files of the officers and why it is relevant and material to the defence. ${ }^{20}$ In order to compel the revelation of the identity of an undercover informant, the defence must show that he/she is a material witness to the guilt or innocence of the accused. ${ }^{21}$

After a reasoned motion by the defence an in camera hearing is usually ordered in which the judge decides whether to reveal the information, without the participation of the defendant or defence counsel. In cases involving the revelation of evidence in police personnel files, a representative of the police internal affairs department takes part in the in camera hearing and shows the judge the content of the citizens' complaints in question or other material in the files. ${ }^{22}$ It is within the judge's discretion whether or not to order an in camera hearing when the defence moves to reveal the identity of an undercover informant. ${ }^{23}$ If held, the prosecutor will usually be present and often the informant himself ${ }^{24}$ and the police officer supervising him. The judge must decide whether the necessity to reveal the identity of the informant outweighs the reasons for keeping it secret. ${ }^{25}$ At the hearing the police officer and/or the informant are placed under oath and questioned ${ }^{26}$ and the defence may submit questions in writing which the judge will ask the witnesses. ${ }^{27}$ The hearing is transcribed verbatim by the court reporter and placed under seal in case the decision of the judge is challenged on appeal. ${ }^{28}$

Before the courts reveal privileged evidentiary material the 'inherent probative value of the information' is weighed against the possibility of introducing other evidence, in order to determine if the necessity of revelation is 'sufflciently clear and significant' in order to outweigh the privilege of confidentiality. ${ }^{29}$

1974).

${ }^{20}$ Cal. Evid. Code $\$ 1043(a)$; Pitchess v. Superior Court, 113 Cal. Rptr. 897 (Cal.

${ }^{21}$ Cal. Evid. Code $\$ \S 1042(c, d)$.

${ }^{22}$ Cal. Evid. Code $\$ 915$.

${ }^{23}$ They are seldom ordered and the denial of a motion to do so does not constitute abuse of discretion. In re Benny $S_{\cdot}, 281$ Cal.Rptr. 1 (Cal.App. 1991); W.S. White, .Evidentiary Privileges and the Defendant's Constitutional Right to Introduce Evidence‘, in 80 Joumal of Criminal Law and Criminology 377, 391 (Note 64).

${ }^{24}$ lt is within the judge's discretion whether the informant shall give testimony in the hearing. People v. Gordon, 270 Cal. Rptr. 451 (Cal. 1990).

${ }^{2}$ Reasons for refusing to reveal his identity are preservation of the usefulness of the undercover informant in future investigations, United States v. Whitney, 633 F.2d 902 ( $9^{\text {th }}$ Cir. 1980), People v. McShann, 330 P.2d 33, 35 (Cal. 1958), as well as, naturally, to protect him from being murdered or subject to other acts of revenge. People v. Towler, 181 Cal. Rptr. 391, 396 (note 4) (Cal. 1982).

${ }^{26}$ People v. Lee, 270 Cal. Rptr. 799 (Cal. App. 1985); United States v. Fixen, 780 F.2d 1434 (9t Cir. 1986); People v. Darden, 465 N.Y.S. 2d 896 (N.Y. 1983).

${ }^{27}$ People v. Galante, 192 Cal. Rptr. 184, 186 (Cal. App. 1983).

${ }^{28}$ Cal. Evid. Code $\S 1042(d)$.

${ }^{29}$ United States ex. Rel. Blackwell v. Franzen, 688 F.2d 496 ( $7^{\text {th }}$ Cir. 1982); Rubio v. Superior Court, 202 Cal. App. 3d 1343 (1988). 
The identity of the informant is revealed when it becomes apparent that he is, for instance, an accomplice in the commission of the charged crimes, ${ }^{30}$ an eyewitness to the crime or the period leading up to its commission, ${ }^{31}$ or otherwise a 'material witness' in relation to the guilt question. ${ }^{32}$ When the defence raises the excuse of entrapment and maintains that the informant unlawfully encouraged the defendant to commit the crime, the identity of the informant may also be revealed. ${ }^{33}$ If, however, the informant only turns over information to the police without being a participant or witness, his identity need not be revealed. ${ }^{34}$

Once a motion to reveal the informant is granted, the prosecutor must decide whether to reveal the identity of the informant, turn over the evidence sought by the defence, or accept the imposition of appropriate sanctions. The sanctions are either:

(1) dismissal of the charges related to the privileged material; ${ }^{35}$

(2) findings of fact or instructions to the jury favorable to the position of the defence in relation to the privileged information; ${ }^{36}$ or

(3) prohibition of the testimony of the police officer or striking his previous testimony from the record. ${ }^{37}$ It is a reversible error if the court unlawfully rejects a motion of the defence to reveal confidential evidentiary material. ${ }^{38}$

After the identity of an informant has been revealed, the prosecutor in California must make all reasonable efforts to ascertain his/her whereabouts so that the defence may interview him or subpoena him to court. ${ }^{39}$

${ }^{30}$ People v. McShann, 330 P.2d 33, 35 (Cal. 1958).

${ }^{31}$ Cf., however, People v. Garcia, 67 Cal. Rptr. 110 (Cal. 1967) (eyewitness always relevant and material) with People v. Lanfrey, 251 Cal. Rptr. 189 (Cal. App. 1988) (denial of revelation because the eyewitness would not have been able to provide exculpatory evidence). Cf. United States v. Ayala, 643 F.2d 244 ( $5^{\text {th }}$ Cir. 1981); State v. Gray, 926 S.W.2d 29 (Mo.App. 1996). But see Sturgess v. United States, 633 A.2d 56 (D.C.App. 1993), where the revelation of the identity of an informant was denied, who was eyewitness to a drug sale, because the defence posed written questions to the informant, the answers to which were read at the trial and where no in camera hearing was requested.

${ }^{32}$ People v. Viramontes, 149 Cal. Rptr. 607 (Cal. App. 1978).

${ }^{33}$ Twiggs v. Superior Court, 194 Cal. Rptr. 152 (Cal. 1983).

${ }^{34}$ United States v. Barnes, 486 F.2d $776\left(8^{\text {th }}\right.$ Cir. 1973).

${ }^{35}$ People v. Goliday, 106 Cal. Rptr. 113, 122 (Cal. 1973).

${ }^{36}$ People v. Rodgers, 126 Cal. Rptr. 719, 724 (Cal. App. 1976) (that the informant would have testified that the defendant was innocent); Kelvin L. v. Superior Court, 133 Cal. Rptr. 325, 331 (Cal. App. 1976) (that the police officer had previously used force against other citizens or had revealed traits of dishonesty on prior occasions).

${ }^{37}$ Priestly v. Superior Court, 330 P.2d 39 (Cal. 1958).

${ }^{38}$ People v. Memro, 214 Cal. Rptr. 832, 830 (Cal. 1985).

${ }^{39}$ Eleazer v. Superior Court, 83 Cal. Rptr. 586, 588 (Cal. 1970). And if an informant was overseas and returns to the U.S., the prosecutor must inform the defence of this fact. United States v. Formanczyk, 949 F.2d 526 ( $1^{\text {st }}$ Cir. 1991). 
During the 'War against Drugs' a new privilege of confidentiality has been developed in the case law to protect secret observation posts used by police to observe the sale of controlled substances ('observation post privilege'). ${ }^{40}$ In some jurisdictions this privilege falls under the statutory privilege accorded to 'official information'. ${ }^{41}$ In cases where the only witness to the alleged guilt of the defendant is the police officer who claims to have seen the act from the secret observation post and the defence claims that it would be impossible to cross-examine the witness without exact knowledge as to the place where he observed the act, the location is usually revealed. ${ }^{42}$

\section{State Security and the CIPA}

The more urgent the state interest in protecting the confidentiality of evidentiary material, the better chance the defence has to achieve the dismissal of the indictment or of individual charges with a properly formulated discovery motion. In the case of state secrets (but also the revelation of the identity of informants), achieving a dismissal is the main reason for defence discovery motions. ${ }^{43}$

In 1980 the U.S. Congress passed the CIPA, ${ }^{44}$ which aimed to harmonize a defendant's right to obtain and present exculpatory evidence and the government's right to protect classified material and minimize threats by defendants to disclose classified information during the course of the trial, socalled 'graymail'. 45 The Act defines 'classified information' as

'any information or material that has been determined by the United States Government pursuant to an Executive order, statute, or regulation to require protection against unauthorized disclosure for reasons of national security.... 46

If the defendant makes a request of discovery for information which contains classified material, the court may authorize the prosecution 'to delete specified items of classified information from documents to be made available to the defendant through discovery', to 'substitute a summary of the information for

${ }^{40}$ United States v. Foster, 986 F.2d 541 (D.C.Cir. 1993).

${ }^{41}$ Cal. Evid. Code \$1040; People v. Montgomery, 252 Cal. Rptr. 779 (Cal. 1988); State v. Garcia, 618 A.2d 326 (N.J. 1993).

${ }^{42}$ United States v. Foster, 986 F.2d 541 (D.C.Cir. 1993); Commonwealth v. Lugo, 548 N.E.2d 1263 (Mass. 1990); State v. Zenquis, 618 A.2d 335 (N.J. 1993).

${ }^{43}$ T. J. Shea, CIPA Under Siege: the Use and Abuse of Classified Information in Criminal Trials, in 27 Am. Crim. L. Rev., 657,659 (1990).

${ }^{44}$ Pub. L. 96-456, Oct. 15, 1980, 94 Stat. 2025.

${ }^{45}$ United States v. Pappas, 94 F.3d 795 ( $2^{\text {nd }}$ Cir. 1996).

${ }^{46} 18$ U.S.C. App. 3 \$1(a). This definition has been upheld against challenges that it was unconstitutionally vague. United States v. Wilson, 571 F.Supp. 1422 (S.D.N.Y. 1983); United States v. Jolliff, 548 F.Supp. 229 (C.D. Md. 1981). 
such classified documents, or to substitute a statement admitting relevant facts that the classified information would tend to prove' ${ }^{47}$

If the defendant is already in possession of classified information and 'reasonably expects to disclose or to cause the disclosure of classified information in any manner in connection with any trial or pretrial proceeding' involving his prosecution, he must notify the prosecutor within thirty days prior to trial of such intention. Disclosure of such information is prohibited until notice has been given and the U.S. Attorney has had a chance to litigate the issue of disclosure under the Act. ${ }^{48}$ If the defendant fails to comply with the 30-day notice requirement, the court may preclude him/her from disclosing any classified information. ${ }^{49}$ Challenges claiming the provision requiring the defence to divulge its intent to rely on classified information violates the privilege against self-incrimination by revealing the defence posture and lightening the burden of the prosecution in securing a conviction have been uniformly rejected. ${ }^{50}$

The procedure for deciding whether to allow revelation of classified information is similar to the procedure described above in normal criminal cases. The U.S. Attomey may request a hearing to be held in camera if he/she alleges that a public proceeding may result in the disclosure of classified information. ${ }^{51}$

The CIPA does not provide any guidance to the court in deciding whether or not to allow disclosure of arguably classified material. To fill this gap, the courts have been using the 'relevant and helpful to the defence' test from United States $v$. Roviaro, fashioned to deal with the revelation of the identity of informants. ${ }^{52}$ Critics have claimed that the Roviaro test was designed specifically for the informant situation and that the usual standard of relevance for federal trials should be applied..$^{53}$ Using the standard rules of evidence, a judge may still exclude otherwise relevant classified evidence in his/her discretion if it is determined that its probative value is outweighed by its prejudicial effect. ${ }^{54}$ It has also been a subject of criticism that judges take the allegedly classified nature of documents

4718 U.S.C. App. $3 \S 4$.

48 U.S.C. App. $3 \$ 5(\mathrm{a})$.

4918 U.S.C. App. $3 \$ 5$ (b). In United States v. Badia, 827 F.2d 1458 (11 $1^{\text {th }}$ Cir. 1987) the sanction of exclusion was applied.

${ }^{50}$ United States v. Wilson, 750 F.2d 7 ( $2^{\text {nd }}$ Cir. 1984); United States v. Poindexter, 725 F.Supp. 13 (D. D. C. 1989); United States v. Jolliff, 548 F.Supp. 229 (C.D. Md. 1981).

18 U.S.C. App. $3 \S 6($ a).

${ }^{52}$ United States v. Pringle, 751 F.2d 419,428 (1 ${ }^{\text {st }}$ Cir. 1984); United States v. Badia, 827 F.2d 1458, 1461 (11 $1^{\text {th }}$ Cir. 1987); United States v. Yunis, 867 F.2d 617 (D.C.Cir. 1989) (mere showing of theoretical relevance not enough, must be 'helpful' to the defence.).

${ }^{53}$ Contained in FRE 401. For examples, see United States v. Juan, 776 F.2d 256,

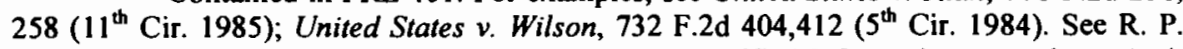
Salgado, ,Government Secrets, Fair Trials, and the Classified Information Procedures Act', in 98 Yale Law Journal, 436-437 (1988).

${ }^{54}$ United States v. Wilson, 750 F.2d 7, 9 (2 ${ }^{\text {nd }}$ Cir. 1984). 
into consideration before they rule on relevancy, rather than ruling on relevancy and then deciding whether to admit the information. ${ }^{55}$

It is also apparent that courts are more narrowly construing the federal discovery statutes when there is an issue of national security. Thus in the case of a man with previous ties to the CIA who hijacked an airplane to Cuba, the defendant moved for discovery of information which he claimed would bolster his defence that he thought the CIA had authorized him to hijack the plane to infiltrate Cuba. The court even denied discovery of his own statements that were included in the classified information although statements of the defendant are routinely included in discovery pursuant to Fed. Rule Crim. Proc. $16^{56}$

Defence motions to discover classified information are usually aimed at disclosing:

(1) information pertaining directly to the proof of the charge that is most likely to be admitted;

(2) information related to a 'preoccupation defence', i.e., that the defendant was 'preoccupied' with national security work at the time of the alleged offense, which has the greatest likelihood of being deemed relevant if it concerns events that occurred simultaneously with the acts forming the basis of the charge; and

(3) classified evidence showing defendant's good character, i.e., that defendant is a hero due to his work as a spy, etc. ${ }^{57}$

The so-called 'CIA defence', whereby the defendant claims the alleged criminal acts he committed were carried out while on duty for the CIA, has been asserted by coveral defendants. ${ }^{58}$

If the judge, following the in camera hearing, determines that specific classified information should be disclosed or that the defendant may introduce classified information to which he is privy, the U.S. Attorney may move that, in lleu of such disclosure, the court order:

${ }^{55}$ R. P. Salgado, supra note 53, at 442 et seq. See also United States v. BaptistaRodriguez, 17 F.3d 1354 ( $11^{\text {th }}$ Cir. 1994), coming to the same conclusion.

${ }_{56}$ United States v. Yunis, 867 F.2d 617, 623 (D.C.Cir. 1989).

${ }^{57}$ S. M. Pilchen and B. B. Klubes, ,Using the Classified Information Procedures Act in Criminal Cases: A Primer for Defense Counsel', in 31 Am. Crim. L. Rev. 191, 199201 (1994). Both the second and third types of information were sought in United States $v$. (ieorge, 786 F.Supp. 56, 59,62 (D.D.C. 1992).

${ }^{58}$ See United States $\nu$. Rewald, 889 F.2d 836, amended on other grounds, 902 F.2d 18, cert. Denied 498 U.S. 819 (1990); United States v. Lopez-Lima, 738 F. Supp. 1404, 1408 (S.D. Fla. 1990) (defendant claims he was working for CIA when he hijacked a plane to Cuba. For discussion of 'CIA Defence' see J. Jarvis, ,Protecting the Nation's National Security: the Classified Information Procedures Act', in 20 T. Marshall L. Rev. 319, $327-$ 332 (1995). 
(1) 'the substitution for such classified information of a statement admitting relevant facts that the specific classified information would tend to prove', ${ }^{, 59}$ or

(2) 'the substitution for such classified information of a summary of the specific classified information'. ${ }^{60}$

In order to allow the substitution of statements admitting relevant facts or summaries, the court must find that the statement or summary 'will provide the defendant with substantially the same ability to make his defence as would disclosure of the specific classified information'.61 If writings, recordings or photographs containing classified information are admitted into evidence, the court may order that only part thereof be admitted or that the classified material be removed or blocked out. The government may also object to any questions of witnesses that would require the disclosure of classified material. ${ }^{62}$

Where the court decides not to order disclosure, the record of the in camera hearing is sealed and no one is permitted to divulge the information publicly. ${ }^{63}$ If the court decides the classified material must be disclosed and the government files an affidavit with the court objecting to the disclosure, the court order that the defendant not disclose the information but dismiss the indictment unless 'the court determines that the interests of justice would not be served by dismissal of the indictment of information'. In such case, the court may:

(1) dismiss specified counts of the indictment or information;

(2) 'make a finding against the government on any issues as to which the excluded classified information related'; or 'strike or preclude all of part of the testimony of a witness' ${ }^{64}$

Where the court has ordered disclosure, the U.S. Attorney may file an interlocutory appeal to the court of appeals during trial to contest the finding. ${ }^{65}$ During the trial of Oliver North arising from the Iran-Contra scandal, the judge ruled that the government's proposed statement of substitutions and summaries for classified information was inadequate to protect North's interests. Independent Counsel Lawrence Walsh refused to appeal the ruling, but the U.S. Attorney sought to stay the trial and appeal. The courts held that the independent counsel had sole authority under CIPA to file an interlocutory appeal. ${ }^{66}$ The courts came to a similar conclusion in the case against Joseph Fernandez, a former CIA service officer, which also stemmed from the Iran-Contra scandal. Referring to the Ethics

\footnotetext{
${ }^{59} 18$ U.S.C. App. $3 \S 6(\mathrm{c})(1)(\mathrm{A})$.

${ }^{60} 18$ U.S.C. App. $3 \S 6(\mathrm{c})(1)(B)$.

${ }^{61} 18$ U.S.C. App. $3 \S 6(\mathrm{c})(1)$.

6218 U.S.C. App. $3 \$ 8$.

${ }^{63} 18$ U.S.C. App. $3 \S 6(d)$

${ }^{64} 18$ U.S.C. App. $3 \S 6(\mathrm{e})(2)$

${ }^{65} 18$ U.S.C. App. $3 \$ 7$
}

${ }^{66}$ United States $v$. North, 713 F. Supp. 1441, 1441 (D.C.C. 1989) aff'd 887

F.2d 465 . 
In Government Act that created the office of the Independent Counsel in wake of the Watergate Scandal to investigate wrongdoing in the executive branch of povernment and transferred to the Independent Counsel 'full power and Independent authority to exercise all investigative and prosecutorial functions and powers', ${ }^{67}$ the Court of Appeals for the Fourth Circuit held that the Act also gave the Independent Counsel the power to completely control the prosecution in cases involving the CIPA. While the Attorney could still independently seek an affidavit to protect information as being classified in a case prosecuted by the Independent Counsel, ${ }^{68}$ appeals of decisions allowing disclosure of such evidence could only be made by the Independent Counsel. ${ }^{69}$

In cases involving the Independent Prosecutor, one sees how an Independent Counsel could seek to disclose information that would help in prosecuting a former CIA agent, for instance, and the Attorney General could seek to prevent this by filing affidavits claiming national security. ${ }^{70}$ This points to the irony of a statute designed to bring the intelligence agencies under legal control, thus leading instead to the creation of a de facto official secrets act that can result in impunity for executive officials who are privy to classified information."

Defendants have also challenged CIPA by alleging that it violates the right to counsel guaranteed by the $6^{\text {th }}$ Amendment of the U.S. Constitution by requiring security clearances of defence counsel before they may be given access to classified information. Under powers conferred by CIPA, ${ }^{72}$ the Chief Justice of the Supreme Court has promulgated rules providing that '[no] person appointed by the court or designated for service therein shall be given access to any classified information in the custody of the court, unless such person has received a security clearance'. ${ }^{73}$ Courts have rejected, however, the claim that such a security clearance procedure violates the right to counsel. ${ }^{74}$

The CIPA has also been criticized because the procedures in cases of 'graymail' have tumed out to be exceedingly costly. For instance, in the case against Oliver North requests were made for discovery of over 700,000 documents and the defence team was furnished a special 'Sensitive Compartmented Information Facility' to examine the documents at a cost of $\$ 336,000$ a year. In the

${ }^{67} 28$ U.S.C. $\$ 594($ a).

${ }^{68} 18$ U.S.C. App. $3 \S 6(\mathrm{e})$.

${ }^{69}$ United States v. Fernandez, 887 F.2d 465, 466 ( $4^{\text {th }}$ Cir. 1989).

${ }^{70}$ For discussions of the problems which arise when C1PA and the Ethics in Government Act (lndependent Counsel Statute) collide, see D. I. Greenberger, ,An Overview of the Ethical Implications of the Classified Information Procedures Act ${ }^{t}$, in 12 Georgetown Joumal of Legal Ethics 151, 159-163 (1998).

${ }^{71}$ Ibid., at 158.

${ }^{72} 18$ U.S.C. App. $3 \$ 9$

7394 Stat. 2025, 4 .

${ }^{74}$ Uniled States v. Jolliff, 548 F. Supp. 232, 233 (D. Md. 1981). Cf. United States v. Musa, 833 F. Supp. 752-755-57 (E.D. Mo. 1993) (requiring persons assisting defence counsel to obtain court approval from the Court Security Officer before being given access to classified information). 
Iran-Contra cases the government utilized more than 54 lawyers and spent more than $\$ 25$ million dollars to prosecute the cases. ${ }^{75}$

\section{Conclusion}

The similarity between the provisions of Article 72 of the Rome Statute and the U.S. approach to resolving collisions between so-called national security interests and the right to present evidence at trial is readily apparent. While in the U.S. it is usually the defendant who seeks to reveal evidence protected by a privilege of confidentiality, the same principles would apply when an Independent Prosecutor, such as under the Rome Statute, or a judge with powers to gather and introduce evidence would make a similar request.

The tactical usage of motions to pierce the national security privilege is colored, of course, by the fact that it is usually a jury that decides the issue of guilt. Defence lawyers often seek to disclose informants or to use 'graymail' either to compel a dismissal of the case in the event the state does not want to disclose the relevant classified evidence, or to actually present what they may think is sympathetic ('hero defence') or scandalous evidence to the jury, perhaps to achieve an acquittal through jury nullification. Imagine if former Panamanian dictator General Manuel Noriega could have introduced at trial the fact that the CIA had tolerated or encouraged his drug smuggling operations as long as he acted as a counterspy against Cuba or Nicaragua? Would a jury have convicted?

Where, as under the Rome Statute, professional judges are responsible for deciding questions of fact and law, findings of fact adverse to the state claiming national security could lead to an acquittal, even if the court does not have the power to outright dismiss the case in the event of a refusal to disclose. 